\title{
Cultural and Emotional Intelligence: Its Role in the Cross-Cultural Adjustment of Filipino Expatriates in the Kingdom of Saudi Arabia
}

\author{
Ramil A. Dinglasa \\ School of Business and Governance \\ Ateneo de Davao University \\ Davao City, Philippines \\ E-mail: dinglasa.ramil@gmail.com
}

Received: Jan. 5, 2020 Accepted: Feb. 5, 2020 Online published: Feb. 17, 2020

doi:10.5296/ijhrs.v10i1.16488ＵRL: https://doi.org/10.5296/ijhrs.v10i1.16488

\begin{abstract}
With the rise of globalization, labor migration is estimated to increase as developed countries will experience shortages in skills of certain age brackets of the working population, thus, requiring more migrant labor in order to address this gap. Filipinos represent a considerable number of expatriates around the world. By 2018, there were 2.3 million Overseas Filipino Workers (OFW), and $24.3 \%(558,900)$ of them worked in Saudi Arabia. These expatriates pursue economic opportunities in the Kingdom due to better job prospects and higher earning potential despite the cross-cultural adjustment challenges. This study aims to explore the influence of Cultural and Emotional intelligence in the cross-cultural adjustment of Filipino expatriates in Saudi Arabia. A survey was conducted on 483 male OFWs, both descriptive and correlational research methods were used to test the hypotheses. Correlation results showed the significant positive associations with moderately strong correlations between cultural intelligence (CQ) and the cross-cultural adjustment of Filipino expatriates in Saudi Arabia. Behavioral and motivational CQ could significantly predict the cross-cultural adjustment of Filipino expatriates. Emotional intelligence (EQ) and the expatriate Filipino's cross-cultural adjustment in Saudi Arabia showed significant association, with Appraisal and Recognition of Emotion in Others as its strongest predictor. The Filipino expatriates' status, first time or seasoned, significantly moderated the association between EQ factors and their cross-cultural adjustment degree. This study suggests that high CQ and EQ levels along with previous experience with the host country could serve well as important considerations in international careers. This paper contributes a new perspective to the literature on Filipino
\end{abstract}


expatriate management and cross-cultural adjustment.

Keywords: Filipino expatriate, Overseas Filipino Workers (OFW), emotional intelligence, cultural intelligence, cross-cultural adjustment

\section{Introduction}

As globalization upsurge, the world can expect to witness even more workers migrating across international borders, specifically going from lower-income countries to higher-income ones. Migration is expected to increase in the future because developed countries will experience shortages in certain age brackets and particular skill sets of the working population, thus requiring more migrant labor.

This trend is well underway with about 272 million people having migrated to other countries outside their country of birth and, as a United Nations report elaborated, "Migration provides immense opportunity and benefits - for the migrants, host communities and communities of origin. However, when poorly regulated it can create significant challenges". It is in this spirit that the United Nations coordinated an international agreement in 2018 called Global Compact for Safe, Orderly and Regular Migration.

This paper aims to support that process by increasing insight into the cross-cultural adjustment challenges of Filipino workers in Saudi Arabia. Filipinos represent a considerable number of expatriates around the world. By 2018, there were 2.3 million Overseas Filipino Workers (OFW), and 24.3\% (558,900) of them worked in Saudi Arabia (Perez, 2018). These expatriates, or "expats," pursue economic opportunities in the Kingdom due to better prospects for job and higher earning potential. However, despite those opportunities, $67 \%$ of expatriates surveyed by (HSBC Expat Explorer, 2014) did not see Saudi Arabia as a long-term option and they were considering going somewhere else.

Scholars regard these problems as having real and workable solution: "This Saudi/Filipino cultural 'odd couple' has been mutually beneficial for several generations but at least for Filipinos, as may be with many who experience transnational migration to a foreign land, the experience is not without misunderstanding, nostalgia, pain, loneliness, and/or sacrifice" (Magliveras, 2019, p. 503). The primary challenge - and what lies at the root cultural adjustment problems - is that the Philippines and Saudi Arabia differ significantly in terms of customs, manners, and gender relations, even though about $10 \%$ of the population in the Philippines is Muslim. The cultural distance between the two counties is dramatic because the Philippines has experienced Indian, Chinese and Muslim influence, and then it was a Spanish colony for three centuries before being administered by the US, invaded and occupied by Japan until the Americans returned. Therefore, while it has some collectivist features, it is much less collectivist than China. It may be useful to think of the Philippines as a third indigenous, a third Asian, and a third Western.

In contrast, Saudi Arabia practices a conservative version of Islam, and therefore, its social norms are based on gender segregation and a completely different language, beliefs, religion, lifestyle, and values. In fact, the two societies contrast so sharply that some Filipinos experience intense culture shock upon arrival, showing symptoms of anxiety, helplessness, 
fear, frustration, depressions, anger, and homesickness (Oberg, 1960). Culture shock significantly affects turnover and job performance and negatively affects job satisfaction (Guy and Patton, 1996)

\section{Theoretical and Conceptual Background}

\subsection{Cultural Intelligence (CQ) of the Expatriate}

CQ is a concept that evolved within a specific research paradigm, namely, within the field of multiple intelligences (Gardner, 1993). The meaning of this term has been widely accepted as the "capability to function and manage effectively in culturally diverse settings" (Earley \& Ang, 2003; Ang, Van Dyne, Koh, Templer, Tay, \& Chandrasekar, 2007). Recent scholars have emphasized that cultural intelligence is associated with polyculturalism, which is the recognition that cultures are inter-connected (Bernardo \& Presbitero, 2018). Scholars have also noted that this unique explanatory variable effectively predicts intercultural communication and the ability to receive and process messages in culturally diverse settings (Earley, 2002).

Theoretically, CQ has the following four dimensions: (1) meta-cognitive; (2) cognitive; (3) motivational, and; (4) behavioral (Earley \& Ang, 2003). Interestingly, these dimensions can be mutually reinforcing and, in some contexts, certain combination exert considerable influence on overall CQ, as reported by Gooden, Creque, \& Chin-Loy, (2017).

Meta-cognitive CQ is the process of developing awareness and reflective understanding of different cultures. Specifically, it deals with the cultural consciousness and awareness of expatriates and their ability to cross-examine cultural assumptions.

Cognitive CQ denotes the universal and culture-specific knowledge of expatriates regarding the practices, norms, and conventions of different cultures. This also reflects their knowledge regarding different social, cultural, legal and economic systems (Kim et al., 2006).

Motivational CQ is essential because it reflects the expatriates' ability to engage in greater cultural learning (Xu and Chen, 2017). This concept may be defined as a person's intrinsic interests in accommodating to a new culture and involves their self-efficacy for cross-cultural adjustment (Bandura, 2002). Behavioral CQ denotes the ability of expatriates to perform culturally privileged non-verbal and verbal actions when interacting with people having varying cultural backgrounds (Lin, Chen \& Song, 2012). This means having a flexible and wide range of behavior. An individual having a higher behavioral CQ is generally accepted by the associated group, resulting in better interpersonal relationships.

\subsection{Emotional Intelligence (EQ) of the Expatriate}

EQ and emotions reportedly play a key role in the intellectual functioning of expatriates (Salovey \& Mayer, 1990). The term EQ was first proposed by Salovey and Mayer (1990) who defined it as an enduring ability to understand, manage, identify, and harness the emotions and then use them in cognitive processing. They divided EQ into three categories: (1) appraisal and expression of emotions (self and others); (2) regulation of emotion (in self and others); and (3) utilization of emotions in solving problems (i.e., creative thinking, 
flexible planning, motivation, and redirected attention).

Appraisal and expression of emotions help expatriates recognize others' emotional reactions and cultivate a sense of empathy. Regulation of emotions helps expatriates acknowledge their own and others' moods. This ensures estimation, scrutinization, and regulation of emotions.

Utilization of emotions in solving problems denotes that individuals with positive emotions can recollect information that can help them in creative problem solving. It has been observed that individuals having positive moods "are more likely to give especially unusual or creative first associates to neutral cues” (Salovey \& Mayer, 1990, p. 199).

\subsection{Cross-Cultural Adjustment}

Cross-cultural adjustment denotes the psychological comfort level that an expatriate enjoys with a host culture (Salgado and Bastida, 2017; Black \& Stephens, 1988; Gregersen \& Black, 1991). The literature specifies the following areas of cross-cultural adjustment (Black \& Stephens, 1991): (1) adjustment to general environment (comfort degree with general living conditions, such as food, health facilities and climate); (2) adjustment to interaction with the nationals of the host country; and (3) adjustment to work (job and supervisory responsibilities, and performance standards).

Black's (1988) model of cross-cultural adjustment has been widely used in various studies. The first category of cross-cultural adjustment includes factors that affect the daily lives of expatriates such as food, driving, shopping, housing conditions, health care, and the cost of living. The second category denotes the comfort level of expatriates when they interact and communicate with host nationals in different environments. Finally, the third category of cross-cultural adjustment is defined as the adjustment level of expatriates with respect to their job and work environment (Black et al., 1991).

Cross-cultural adjustment is a primary and temporal outcome in an expatriate's assignment that may affect the more distal or secondary expatriate adjustment such as job satisfaction, strain (Hechanova, Beehr, \& Christiansen, 2003), performance and organizational commitment.

Also, under consideration is how the relationship between types of intelligence and cross-cultural adjustment is moderated by the Profile of the Filipino expatriate (marital/civil status, age, status as expatriate). Here, the study investigates the mediating role of Age as postulated by (Wechtler, Koveshnikov, \& Dejoux, 2015), marital/civil status and expatriate's status whether first time or seasoned/experienced between Filipino expats CQ and CCA and EQ and CCA.

The conceptual framework was mirrored after the study conducted by Lin, Chen and Song (2012), wherein the outcomes of cultural intelligence and emotional intelligence on an individual's adjustment in a different cultural environment were examined. Further, the framework combines the studies of Moon, Choi and Jung (2012) for cultural intelligence, as presented in Figure 1.1, and Koveshnikov, Wechtler and Dejoux (2014) for emotional intelligence in relation to determining cross-cultural adjustment as presented in Figure 1.2. 


\section{Macrothink}

International Journal of Human Resource Studies

ISSN 2162-3058

2020, Vol. 10, No. 1

On Figure 1.1, an expatriate's CQ is believed to be influenced by previous international experience and the cross-cultural training that it went through. This is thought to have shaped their CQ, which has an influence on the expatriate's cross-cultural adjustment.

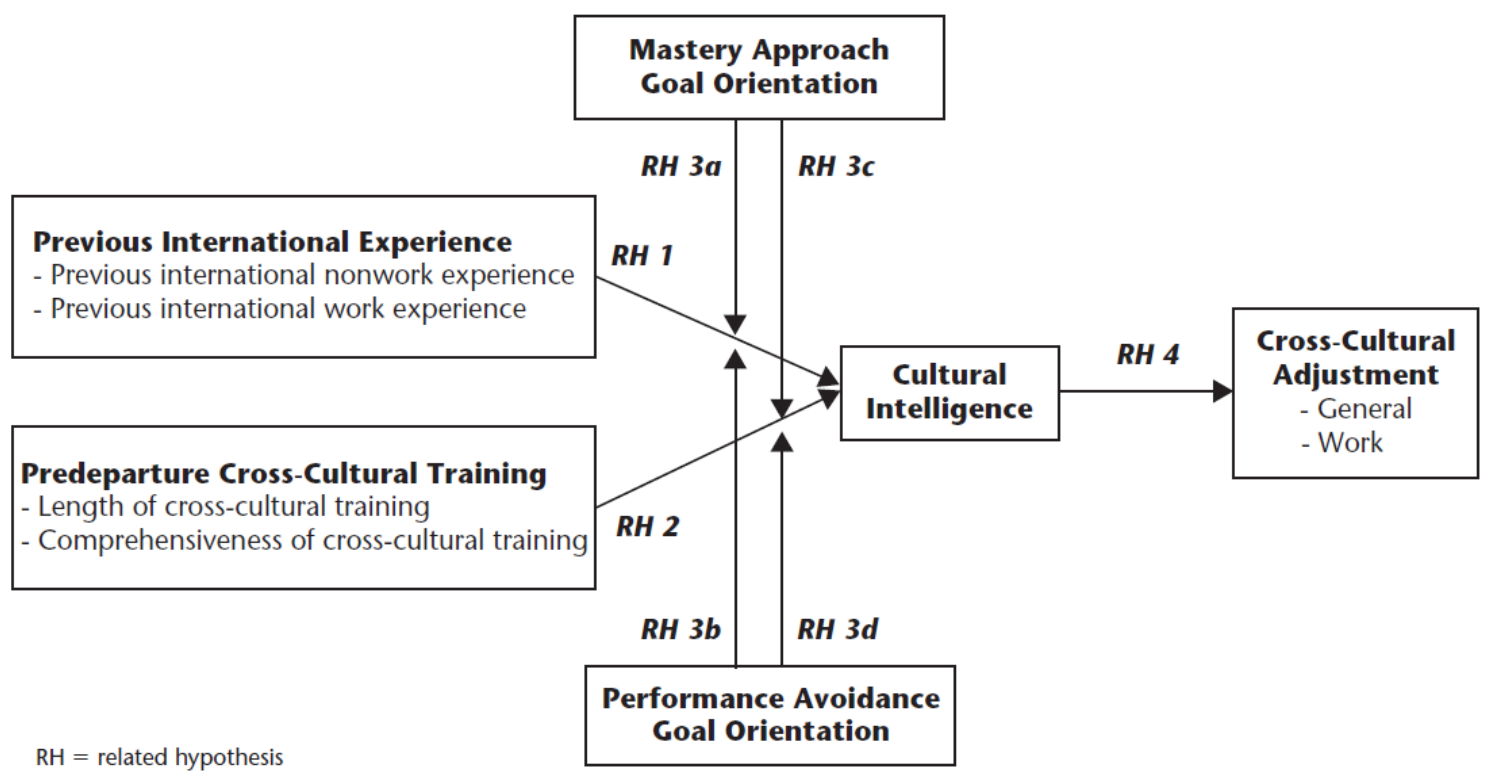

Figure 1.1. Theoretical Model on Cultural Intelligence (CQ) of Moon, Choi and Jung (2012)

Figure 1.2. on the other hand, posited that the expatriate's EQ is instrumental in shaping the manner by which they adjust in the working environment of a host country. This was considered by the researcher as instrumental in shaping an expatriate's cross-cultural adjustment.

\begin{tabular}{|l|}
\hline Emotional intelligence \\
Appraisal and expression of emotions \\
Regulation of emotions \\
Utilization of emotions \\
\hline
\end{tabular}

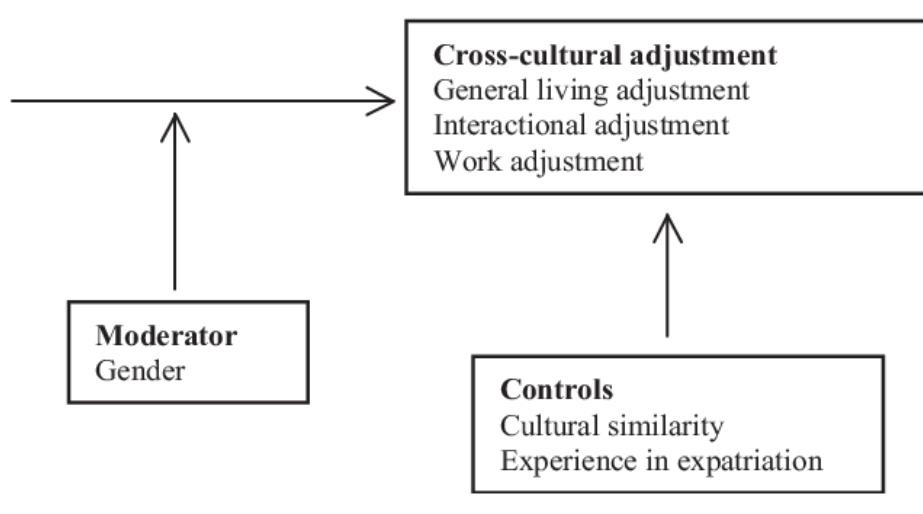

Figure 1.2. Theoretical Model on Emotional Intelligence (EQ) of Koveshnikov, Wechtler and Dejoux (2014)

There are strategies that can be effective in helping individuals overcome culture shock and associated problems. Research shows that migrant workers including Filipinos in Saudi Arabia and elsewhere have successfully relied on a combination of cultural intelligence (behavioral, cognitive, metacognitive, and motivational) and emotional intelligence (expression and appraisal of emotion, recognition and appraisal of emotion in others, use of 
emotion to simulate performance, and regulation of emotion) (B, Shahjehan, SY, \& Wajid, 2019). The figure below (Figure 1.3) shows the relationships at work in this model.

\section{Cultural Intelligence (CQ) of the Filipino Expatriate}

- Metacognitive

- Cognitive

- Motivational

- Behavioral

\section{Emotional Intelligence (EQ) of the} Filipino Expatriate

- Appraisal and Expression of Emotion-Self

- Appraisal and Recognition of Emotion in Others

- Regulation of Emotion-Self

- Use of Emotion to Facilitate Performance

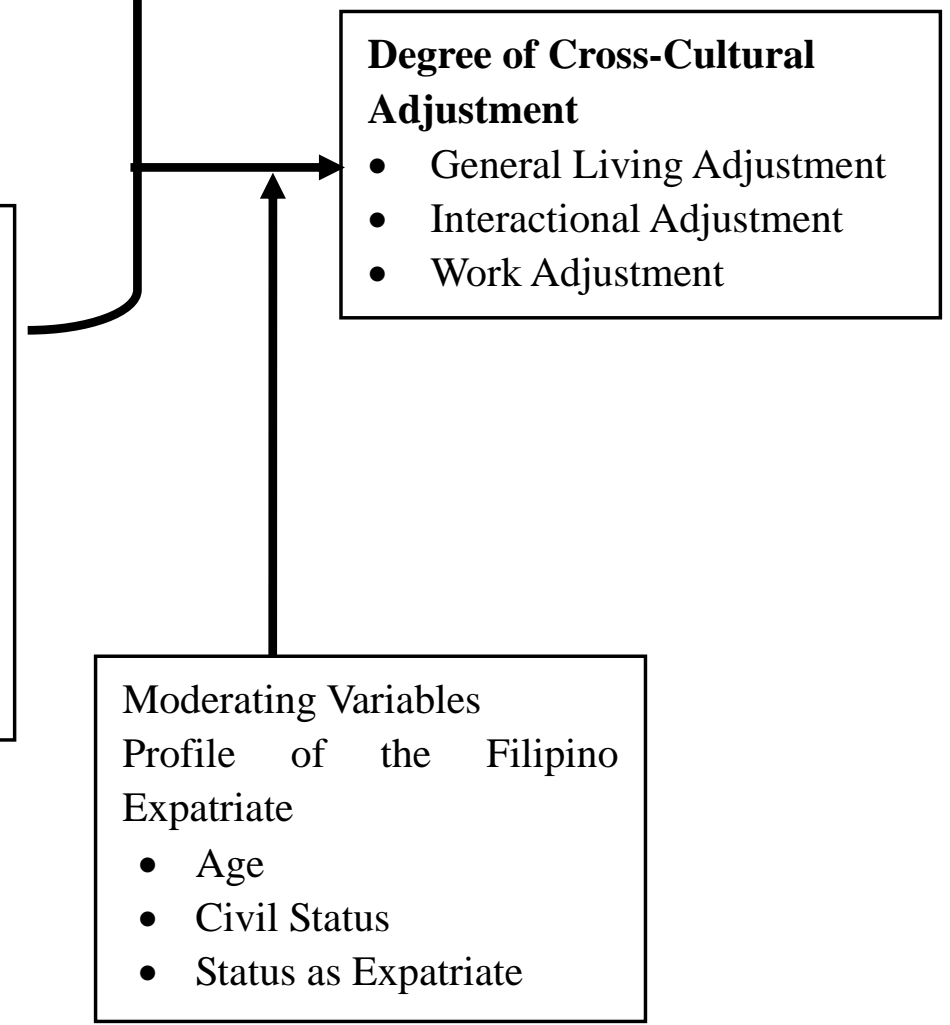

Figure 1.3. Conceptual framework on the relationship between CQ, EQ and CCA as moderated by the profile of Filipino expatriates

\subsection{Hypotheses Formulation}

The observations above allows the researcher to formulate the following hypotheses.

H1a: There is no significant relationship between Filipino expatriate's cultural intelligence (CQ) and their degree of cross-cultural adjustment

H1b: There is no cultural intelligence (CQ) factors that can significantly predict Filipino expatriate's cross-cultural adjustment 
H2a: There is no significant relationship between Filipino expatriate's emotional intelligence (EQ) and their degree of cross-cultural adjustment

$\mathrm{H} 2 \mathrm{~b}$ : There is no emotional intelligence (EQ) factors that can significantly predict the Filipino expatriate's cross-cultural adjustment

H3a: Filipino expatriate's profile cannot moderate the relationship between their CQ and CCA

H3b: Filipino expatriate's profile cannot moderate the relationship between their EQ and CCA

\section{Methods}

\subsection{Sample and Data Collection}

The study covered Filipino male expatriates $(n=483)$ that were presently working in Al-Jubail, Al-Dammam, and Al-Khobar, Saudi Arabia throughout the conduct of this research. The researcher utilized (Cochran, 1963) sampling formula and in the course of determining the composition of the Filipino expatriates as respondents, the researcher used purposive sampling wherein the respondent sample is strategically outlined by the nature and context of the research objectives (Palys, 2008). Only male Filipino expatriates were considered because it's difficult for the researcher to include females since gender segregation are strictly followed (McGarry, 2019) in the Kingdom.

The survey method was used in culling the information of OFW's using questionnaire, wherein the researcher counted the respondent's ability to read and understand the said tool at their most convenient time (Andres, 2012). The said tool was divided into four stages, namely: (1) Respondent's Profile; (2) Cultural Intelligence (CQ) of OFW's; (3) Emotional Intelligence (EQ) of OFW's; and, (4) Degree of Cross-Cultural Adjustment of Filipino expatriates. Part I of the survey questionnaire were arranged in the form of checklist, from which responses can be easily tabulated and measured by the researcher. A Five-point Likert-type scale was used to measure responses for the second, third and fourth stages of the survey tool. The response anchors established by (Vogt, 1999) and (Vagias, 2006) was used in order to rate the response made to the question-items as listed in the survey questionnaire.

\subsection{Measures}

Question-items for cultural intelligence were adapted from the cultural intelligence scale (CQS) developed by Van Dyne, Ang, and Koh (2008) and used by Bucker, Furrer and Lin (2015). Further, the question-items for emotional intelligence were culled from then emotional intelligence scale formed by Wong and Law (2002) and employed by LaPalme, Wang, Joseph, Saklofske and Yan (2016). Lastly, the question-items used to measure the cross-cultural adjustment of Filipino expatriates were derived from the paper of Ward and Kennedy (1999).

A pre-test was conducted, which involved thirty respondents, whose internal consistency and validity of response was measured $(\boldsymbol{\alpha}=\mathbf{0 . 7 6 8})$ (Cronbach, 1951). As one of the reliability 
indices employed to establish a survey questionnaire's internal consistency, the Cronbach's Alpha coefficient was measured using the rules of thumb posited by George and Mallery (2003) (p. 231). Further, Nunnally (1978) posited the coefficients of between 0.70 and 0.80 are acceptable for basic research.

\subsection{Empirical Strategy}

The data gathered went through summarization, interpretation and analysis. Mean and weighted mean, frequency count and percentages were employed to establish the descriptive information of the data. Inferential statistics were utilized to derive answers for the proposed research hypotheses on this study.

The Pearson product-moment correlation coefficient was utilized to measure the strength of relationship between EQ-CCA, and CQ-CCA. Table 3.1, presents the rule of thumb on the strength of correlation coefficients culled from (Hair Jr., Wolfinbarger , Ortinau, \& Bush, 2013). Stepwise regression analysis was used as a prediction tool and hierarchical regression analysis was utilized to determine the moderating influence of the Filipino expatriates' profile. SPSS statistical software was used to analyze the data. Appropriate conclusion and recommendations were drawn out of the results.

Table 3.1. Rules of Thumb on the Strength of Correlation Coefficients

\begin{tabular}{|c|c|c|}
\hline \multicolumn{2}{|c|}{ Range of Coefficient } & \multirow[t]{2}{*}{ Description of Correlation Strength } \\
\hline From & To & \\
\hline$+/-0.81$ & $+/-1.00$ & Very Strong \\
\hline$+/-0.61$ & $+/-0.80$ & Strong \\
\hline$+/-0.41$ & $+/-0.60$ & Moderate \\
\hline$+/-0.21$ & $+/-0.40$ & Weak \\
\hline$+/-0.00$ & $+/-0.20$ & Weak to No Correlation \\
\hline
\end{tabular}

Source: Hair, Jr., Celsi, Oritinau \& Bush (2013)

\section{Results}

Table 4.1 shows the gathered and arranged information of Filipino expatriates in the Kingdom of Saudi Arabia. Most of them were 31-35 years old (22.6\%), 70.4\% were married, and a majority of them were seasoned whose contract has been renewed several times $(74.10 \%)$. 
Table 4.1. Filipino Expatriates Profile $(\mathrm{N}=483)$

\begin{tabular}{|c|c|c|c|}
\hline Variables & Category & Frequency & $\%$ \\
\hline \multirow[t]{9}{*}{ Age } & Below 25 years old & 19 & 3.9 \\
\hline & 25-30 years old & 93 & 19.3 \\
\hline & 31-35 years old & 109 & 22.6 \\
\hline & $36-40$ years old & 104 & 21.5 \\
\hline & 41-45 years old & 69 & 14.3 \\
\hline & 46-50 years old & 47 & 9.7 \\
\hline & 51-55 years old & 25 & 5.2 \\
\hline & 56-60 years old & 15 & 3.1 \\
\hline & Above 60 years old & 2 & 0.4 \\
\hline \multirow[t]{2}{*}{ Civil Status } & Single & 143 & 29.6 \\
\hline & Married & 340 & 70.4 \\
\hline \multirow[t]{2}{*}{ Status as an Expatriate } & First Contract & 125 & 25.9 \\
\hline & Seasoned & 358 & 74.1 \\
\hline
\end{tabular}

Table 4.2 show the weighted mean scores and verbal descriptions of the responses made by Filipino expatriates in terms of their Emotional intelligence, Cultural intelligence and Cross-cultural adjustment. 
Table 4.2. Descriptive statistics

\begin{tabular}{|c|c|c|c|}
\hline & Mean & SD & Verbal Description \\
\hline \multicolumn{4}{|l|}{ Cross-cultural adjustment factors } \\
\hline General living adjustment & 3.66 & 0.69 & To a good extent \\
\hline Interactional adjustment & 3.75 & 0.65 & To a good extent \\
\hline Work adjustment & 3.58 & 0.74 & To a good extent \\
\hline \multicolumn{4}{|l|}{ Cultural intelligence factors } \\
\hline Metacognitive & 3.87 & 0.67 & Agree \\
\hline Cognitive & 3.62 & 0.72 & Agree \\
\hline Motivational & 3.70 & 0.69 & Agree \\
\hline Behavioral & 3.77 & 0.59 & Agee \\
\hline \multicolumn{4}{|l|}{ Emotional intelligence factors } \\
\hline Appraisal \& Expression of Emotion-Self & 4.00 & 0.67 & Agree \\
\hline $\begin{array}{l}\text { Appraisal \& Recognition of Emotion in } \\
\text { others }\end{array}$ & 3.82 & 0.70 & Agree \\
\hline Regulation of Emotion-Self & 4.01 & 0.71 & Agree \\
\hline Use of Emotion to Facilitate Performance & 4.16 & 0.66 & Agree \\
\hline
\end{tabular}

Table 4.3 displays the correlation between variables. The result shows that Cultural intelligence (CQ) factors significantly and positively correlated with the degree of Cross-cultural adjustment of Filipino expatriates. The Motivational Factor showed the highest positive correlation $(\mathrm{r}=0.601$; sig. 0.00). Behavioral factor of $\mathrm{CQ}$ showed the highest positive correlation with General Living Adjustment $(r=0.548$; sig. 0.00$)$ and Motivational factor of CQ showed the highest positive correlation with Interactional Adjustment $(r=0.567$; sig. 0.00) and Work Adjustment $(r=0.490 ;$ sig. 0.00).

Emotional intelligence (EQ) factors significantly and positively correlated with the degree of Cross-cultural adjustment of Filipino Expatriates, and Appraisal and recognition of emotion 
in Others showed the highest significantly positive correlation $(\mathrm{r}=0.473$; sig. 0.00). Appraisal and Recognition of Emotion in Others showed the highest significantly positive correlation, deemed as Moderate, with General Living Adjustment ( $\mathrm{r}=0.435$; sig. 0.00), Interactional Adjustment ( $r=0.477$; sig. 0.00), and Work Adjustment ( $r=0.347$; sig. 0.00).

Table 4.3. Correlation table

\begin{tabular}{|l|l|l|l|l|}
\hline & $\begin{array}{l}\text { Cross- } \\
\text { Cultural } \\
\text { Adjustment }\end{array}$ & $\begin{array}{l}\text { General } \\
\text { Living } \\
\text { Adjustment }\end{array}$ & $\begin{array}{l}\text { Interactional } \\
\text { Adjustment }\end{array}$ & $\begin{array}{l}\text { Work } \\
\text { Adjustment }\end{array}$ \\
\hline Cultural intelligence factors & & & & \\
\hline Metacognitive & $0.442^{* *}$ & $0.410^{* *}$ & $0.415^{* *}$ & $0.349^{* * *}$ \\
\hline Cognitive & $0.550^{* *}$ & $0.538^{* *}$ & $0.508^{* *}$ & $0.413^{* *}$ \\
\hline Motivational & $0.601^{* *}$ & $0.538^{* *}$ & $0.567 * *$ & $0.490^{* *}$ \\
\hline Behavioral & $0.588^{* *}$ & $0.548^{* *}$ & $0.541^{* *}$ & $0.471^{* *}$ \\
\hline Emotional intelligence factors & & & & \\
\hline $\begin{array}{l}\text { Appraisal \& Expression of } \\
\text { Emotion-Self }\end{array}$ & $0.331^{* * *}$ & $0.314^{* * *}$ & $0.340^{* * *}$ & $0.228^{* * *}$ \\
\hline $\begin{array}{l}\text { Appraisal \& Recognition of Emotion } \\
\text { in others }\end{array}$ & $0.473^{* *}$ & $0.435^{* *}$ & $0.477^{* *}$ & $0.347 * * *$ \\
\hline Regulation of Emotion-Self & $0.404^{* * *}$ & $0.405^{* * * *}$ & $0.403 * * *$ & $0.268^{* * *}$ \\
\hline $\begin{array}{l}\text { Use of Emotion to Facilitate } \\
\text { Performance }\end{array}$ & $0.396^{* * *}$ & $0.405^{* * *}$ & $0.422^{* * *}$ & $0.234^{* * *}$ \\
\hline
\end{tabular}

Source: Hair Jr., et al (2013)

Correlation Significant at the 0.01 level (2-tailed)

**Correlation strength Moderate

***Correlation strength Weak

CQ was a significant predictor of the Filipino Expatriate's degree of Cross-cultural adjustment at Model 4 (Appendix 1) by 48.1\%, with the Motivational factor as its strongest predictor $(\beta=0.279$; sig. $=0.00)$. The researcher further investigate which CQ factors can significantly predict CCA factors. The result shows that CQ can significantly predict General Living Adjustment at Model 3 (Appendix 2) by 41.2\%, with the Behavioral factor as its strongest predictor $(\beta=0.289$; sig. $=0.00)$. CQ can significantly predict Interactional Adjustment at Model 4 (Appendix 3) by 41.8\%, with the Motivational factor as its strongest predictor $(\beta=0.292$; sig. $=0.00)$. CQ can significantly predict Work Adjustment at Model 3 (Appendix 4) by $30.1 \%$, with the Motivational factor as its strongest predictor $(\beta=0.313$; sig. $=0.00)$.

EQ is a significant predictor of the Filipino Expatriate's Degree of Cross-Cultural Adjustment at Model 2 (Appendix 5) by 26.2\%, with Appraisal and recognition of emotion in others as its strongest predictor $(\beta=0.321$; sig. $=0.00)$.

The researcher further investigate which CQ factors can significantly predict CCA factors. 
The result shows that EQ can significantly predict General Living Adjustment at Model 3 (Appendix 6) by 22\%, with Appraisal of Emotion in others as its strongest predictor $(\beta=$ 0.267 ; sig. $=0.00)$. EQ can significantly predict Interactional Adjustment at Model 2 (Appendix 7) by 27.7\%, Appraisal and recognition of emotion in others as its strongest predictor $(\beta=0.330$; sig. $=0.00)$. EQ can significantly predict Work Adjustment at Model 1 (Appendix 8) by $12 \%$, with Appraisal and recognition of emotion in others as its strongest predictor $(\beta=0.366$; sig. $=0.00)$.

In considering the aggregated means of cultural intelligence (CQ) and emotional intelligence (EQ) of Filipino expatriates, it was learned in (Appendix 9) that the $2^{\text {nd }}$ model was deemed as the most acceptable in predicting their cross-cultural adjustment by $45.1 \%$. Further, CQ was identified as its strongest predictor $(\beta=0.679$; sig. $=0.00)$. This means that the Filipino expatriates' understanding of the host country's culture contributes largely to their cross-cultural adjustment.

Status as an Expatriate can significantly moderate the relationship between EQ factors and the degree of cross-cultural adjustment of Filipino expatriates, with an increase in $\mathrm{R}^{2}$ by $1.9 \%$ (Appendix 11). However, this is not the case with CQ (Appendix 10).

Table 4.4. Summary of research hypothesis outcomes

\begin{tabular}{|l|l|l|}
\hline No. & Statement & Decision \\
\hline H1a & $\begin{array}{l}\text { There is no significant relationship between Filipino expatriate's cultural } \\
\text { intelligence (CQ) and degree of cross-cultural adjustment }\end{array}$ & Reject \\
\hline H1b & $\begin{array}{l}\text { There is no cultural intelligence (CQ) factors that can significantly predict } \\
\text { Filipino expatriate's cross-cultural adjustment }\end{array}$ & Reject \\
\hline H2a & $\begin{array}{l}\text { There is no significant relationship between Filipino expatriate's emotional } \\
\text { intelligence (EQ) and their degree of cross-cultural adjustment }\end{array}$ & Reject \\
\hline H2b & $\begin{array}{l}\text { There is no emotional intelligence (EQ) factors that can significantly } \\
\text { predict the Filipino expatriate's cross-cultural adjustment }\end{array}$ & Reject \\
\hline H3a & $\begin{array}{l}\text { Filipino expatriate's profile cannot moderate the relationship between their } \\
\text { CQ and CCA }\end{array}$ & Accept \\
\hline H3b & $\begin{array}{l}\text { Filipino expatriate's profile cannot moderate the relationship between their } \\
\text { EQ and CCA }\end{array}$ & Reject \\
\hline
\end{tabular}

\section{Discussion and Conclusion}

The correlation results revealed significant positive associations with moderately strong correlations, indicating that CQ played a key role in helping the Filipino expatriates in Saudi Arabia to undergo cross-cultural adjustment.

This finding is in agreement with that reported by Ramalu, Wei, and Rose (2011), who showed that CQ enables both expatriate job performance and cross-cultural adjustment. Ersoy (2014) also stated that the fundamental aspect of communication is cultural awareness.

The significant positive correlation outcomes with weak to moderate correlation strength denoted that EQ was significantly associated with expatriate Filipino's cross-cultural adjustment. However, this variation indicates that individuals having different EQ scores go 
through cross-cultural processes at different speeds.

Behavioral and motivational CQ significantly affect expatriate Filipino's cross-cultural adjustments, especially in terms of interactions, general living, and work. This finding is consistent with those reported by Ersoy (2014) and Lin, Chen, and Song (2012) among others. Individuals with dynamic motivational CQ can adjust better to living overseas. Wang and Sangalang (2005) reported that Filipino immigrant employees could adjust in the host country if they receive social support from their own groups. This is also true for Filipino expatriates working in Saudi Arabia as they generally attempt to establish relations with the fellow "kabayans" soon after their arrival, usually within the first two weeks. Ang et al. (2007) has reported this observation as their way of making cross-cultural adjustment.

EQ was significantly and positively associated with the degree of cross-cultural adjustment of Filipino expatriates, even though CQ had a higher predictive strength. This is in agreement with the findings of other previously published studies (Gabel, Dolan, \& Cerdin, 2005; Koveshnikov, Wechtler, \& Dejoux, 2014).

Moreover, the low value of $\mathrm{R}^{2}$ may be due to expatriates being less motivated in using their EQ for cross-cultural adjustment because of their previous experiences (Wechtler, Koveshnikov, \& Dejoux, 2014). In general, expatriates having more experiences have less tendency to mobilize their EQ to adapt to another culture. They instead focus on their finances, careers, and personal concerns (Selmer, 2001a, 2001; Osland, 2001). This finding is consistent with that reported by Lii and Wong (2008), i.e., EQ has no effect on expatriate cross-cultural adjustment.

The status of Filipino expatriates, either first time or seasoned, significantly and moderately affected the association between EQ factors and their cross-cultural adjustment degree. This finding was not reported for CQ factors, the outcome is in agreement with the findings reported by Lin, Chen, and Song (2012) and Bhaskar-Shrinivas, Shaffer and Luk (2005) among others. Expatriates having international experience (Selmer, 2001b, 2002) tend to make a successful transition to living in the host country. Conversely, some workers with more language ability and local knowledge can easily identify discrimination and develop negative attitudes (Ensher, Grant-Vallone \& Eonaldson, 2001).

The results show that age does not moderate the relationship between EQ and CCA and CQ and CCA. This is similar to the findings of Pan, Wong, Chan, and Joubert (2008). However, this contradicts the study of Wechtler et al., (2014), as they found out that age is a facilitator of regulation and utilization of emotions on general living adjustment and regulation of emotion on interactional adjustment and Church (1982) who established that young expatriates had a higher level of social contact that leads to interaction with host nationals than elder expatriates.

The marital/civil status of Filipino expatriates indicated no significant moderating influence between EQ and CCA and CQ and CCA. This is parallel to the results of Bright (2008) as she stated that expatriate's adjustment is complicated process and is influenced by many factors. 


\subsection{Implications for Theory}

This study contributes insight to the concept "cultural intelligence" as elaborated by Earley and Ang (2003) by providing empirical support to validate all four CQ dimensions of cross-cultural adjustment of expatriates. It also confirms that EQ can be an enduring personal trait that enhances one's ability to adapt, manage, and use a range of emotions (Salovey and Mayer, 1990). Only two of the EQ constructs considered by Davies, Stankov, and Roberts (1998) proved to be important (Use of Emotion to Facilitate Performance; Appraisal and Recognition of Emotion in Others) in Filipino expatriate's cross-cultural adjustment and as shown by Lin, Chen, and Song (2012), this study found CQ and EQ to be valid predictors of cross-cultural adjustment. Further, the results are in agreement with the theoretical construct that focuses on three areas of cross-cultural adjustment: 1) general environment; 2) interaction with the nationals of the host country; and 3) work.

The results confirm that international experience helps in regulating the relationship between cross-cultural adjustment and CQ. This conformed to the Situated Learning Theory. Gradual exposure to a host country's culture enabled expatriates to learn the more nuanced and subtle aspects of the culture. Finally, this study supports Socio-emotional Selectivity Theory because the findings show that middle-aged Filipino expatriates focus on emotionally meaningful goals and obtaining social and cognitive resources. Expectedly, such expatriates tend towards emotional regulation (Wechtler, Koveshnikov, \& Dejoux, June 2015).

\subsection{Implications for Practice}

Cultural intelligence (CQ) opens up interaction opportunities with various cultures by cultivating a sense of flexibility, sympathy, and by embracing a diverse cultural tradition, that is thought provoking, gratifying, and empowering (Ersoy, 2014). It is possible to use CQ to leverage differences in the workplace such that they become a mechanism for change and for more meaningful cross-cultural adjustment, irrespective of the host country.

Multinational organizations should identify and hire emotionally intelligent individuals belonging to different countries as expatriates. After all, high EQ levels have positive effects on the cross-cultural adjustment and, consequently, workplace performance of expatriates (Koveshnikov, Wechtler, \& Dejoux, 2014). Black, J. S., \& Mendenhall, M. (1989) pointed out that inadequate understanding of the variables and the lack of appropriate training methods can affect cross-cultural adjustment.

This study suggests that high CQ and EQ levels can contribute to important considerations in international careers. Gooden, Creque, \& Chin-Loy (2017) advice that companies need to integrate the concepts of cultural and emotional intelligence into their expatriate development programs and have their prospective candidates undergo various stages of motivation, awareness, and action/reaction while on their path to becoming cross-culturally skillful. In addition, those individuals with high motivational CQ scores or prior overseas experience could be prioritized for certain kinds of international work. Training modules should place a stronger emphasis on behavioral and motivational CQ.

This study has implications for real-world practice, and its results can help guide employers 
and HR practitioners in designing programs for employee screening, recruitment, and selection, and as they follow up the hiring process with cross-cultural training.

\subsection{Implications for Research}

This study showed that both EQ and CQ significantly predict the degree of cross-cultural adjustment of Filipino expatriates. However, to validate this finding, further research is recommended such as comparative study involving other Middle Eastern countries with large numbers of Filipino expatriates including women as gender may influence cross-cultural adjustment (Hechanova, Beehr, \& Christiansen, 2003). In addition, other variables and predictors as well as multivariate tools can be explored and considered to model the interaction between EQ, CQ and cross-cultural adjustment. Findings can also be compared across different age groups, industries, source countries, and host countries.

\section{Recommendation}

This study offers the following recommendations:

\subsection{For the Employers Based in Saudi Arabia and Recruiting Agencies}

a. Employers should develop a pre-employment seminar for both first time and seasoned Filipino expatriates before and after their arrival in Saudi Arabia. Training and seminars should provide problem-solving cultural scenarios, case studies, workshops, and mentoring programs (Lin, Chen, Song, 2012).

b. Employers, should sponsor activities that encourage socialization among expatriates and host nationals.

c. Employers should periodically assess its expatriate employees in terms of their cultural adjustment, the problems encountered, and how the problems were addressed.

d. Employers with their HR Directors should plan, implement, and periodically review its employment strategies for expatriates. In particular, employers should develop cultural adjustment programs for team building, cultural awareness week, and open days.

\subsection{For the Government}

a. Review its present pre-employment program for Filipino expatriates and assess its effectiveness, and further improve its program design based on real-time data gathered on the countries of destination.

\section{References}

Afsar, B., Shahjehan, A., Shah, S. Y., \& Wajid, A. (2019). The mediating role of transformational leadership in the relationship between cultural intelligence and employee voice behavior: A case of hotel employees. International Journal of Intercultural Relations, 69, 66-75. https://doi.org/10.1016/j.ijintrel.2019.01.001

Andres, L. (2012). Designing \& doing survey research, 55 City Road, London: SAGE Publications, Ltd. https://doi:10.4135/9781526402202 
Ang, S., Van Dyne, L., Koh, C., Ng, K. Y., Templer, K. J., Tay, C., \& Chandrasekar, N. A. (2007). Cultural Intelligence: Its measurement and Effects on Cultural Judgment and Decision Making, Cultural Adaptation, and Task Performance. Management and Organization Review, 3, 335-371. https://doi.org/10.1111/j.1740-8784.2007.00082.x

Bandura, A. (2002). Social cognitive theory in cultural context. Applied Psychology: An International Review, 51, 269-290. https://doi.org/10.1111/1464-0597.00092

Bernardo, A., \& Presbitero, A., (2018). Cognitive flexibility and cultural intelligence: Exploring the cognitive aspects of effective functioning in culturally diverse contexts. International Journal of Intercultural Relations, 66, 12-21. https://doi.org/10.1016/j.ijintrel.2018.06.001

Bhaskar-Shrinivas, P., Harrison, D. A., Shaffer, M. A., \& Luk, D. M. (2005). Input-based and time-based models of international adjustment: meta-analytical evidence and theoretical extensions. Academy of Management Journal, 48(2), 257-281. https://doi.org/10.5465/amj.2005.16928400

Black, J. S. (1988). Work role transitions: A study of American expatriate managers in Japan. Journal of International Business Studies, 19(2), 277-294. https://doi.org/10.1057/palgrave.jibs.8490383

Black, J. S., \& Gregersen, H. B. (1991). When Yankee comes home: Factors related to expatriate and spouse repatriation adjustment. Journal of International Business Studies, 22, 671-694. https://doi.org/10.1057/palgrave.jibs.8490319

Black, J. S., \& Mendenhall, M. (1989). A practical but theory-based framework for selecting cross-cultural training methods. Human resource management, 28(4), 511-539. https://doi.org/10.1002/hrm.3930280406

Bright, C. C. (2008). Investigating the relationship between expatriate adjustment, marital status, and related attributes. University of Phoenix.

Bücker, J., Furrer, O., \& Lin, Y. (2015). Measuring cultural intelligence (CQ): A new test of the CQ scale. International Journal of Cross-Cultural Management, 15(3), 259-284. https://doi.org/ 10.1177/1470595815606741

Chen, A. S. Y., Lin, Y. C., \& Sawangpattanakul, A. (2011). The relationship between cultural intelligence and performance with the mediating effect of culture shock: A case from Philippine laborers in Taiwan. International Journal of Intercultural Relations, 35(2), 246-258. https://doi.org/10.1016/j.ijintrel.2010.09.005

Church, A. T. (1982). Sojourner adjustment. Psychological bulletin, 91(3), 540. https://doi.org/10.1037/0033-2909.91.3.540

Cochran, W. G. (1963). Sampling Techniques, Wiley, New York.

Cronbach, L. (1951). Coefficient alpha and the internal structure of tests. Psychomerika, 16, 297-334. https://doi.org/10.1007/bf02310555 


\section{Macrothink}

International Journal of Human Resource Studies ISSN 2162-3058 2020, Vol. 10, No. 1

Davies, M., Stankov, L., \& Roberts, R. D. (1998). Emotional intelligence: in search of an elusive construct. Journal of Personality and Social Psychology, 75(4), 989-1015. https://doi.org/10.1037//0022-3514.75.4.989

Deng, L., \& Gibson, P. (2008). A qualitative evaluation on the role of cultural intelligence in cross-cultural leadership effectiveness. International journal of leadership studies, 3(2), 181-197.

Earley, P. C. (2002). Redefining interactions across cultures and organizations: Moving forward with cultural intelligence. Research in Organizational Behavior, 24, 271-299. https://doi.org/10.1016/s0191-3085(02)24008-3

Earley, P. C., \& Ang, S. (2003). Cultural intelligence: Individual interactions across cultures. Palo Alto: Stanford University Press.

Ensher, E. A., Grant-Vallone, E. J., \& Eonaldson, S. I. (2001). Effects of perceived discrimination on job satisfaction, organizational commitment, organizational citizenship behavior, and grievances. Human Resource Development Quarterly, 12(1), 53-72. https://doi.org/10.1002/1532-1096(200101/02)12:13.0.CO;2-G

Ersoy, A. (2014). The Role of Cultural Intelligence in Cross-Cultural Leadership Effectiveness: A Qualitative Study in the Hospitality Industry. Journal of Yasar University, 35(9), 6099-6108. https://doi.org/10.19168/jyu.83730

Gabel, R. S., Dolan, S. L., \& Cerdin, J. L. (2005). Emotional intelligence as predictor of cultural adjustment for success in global assignments. Career Development International, 10(5), 375-395. https://doi.org/10.1108/13620430510615300

Gardner, H. (1993). Multiple intelligence: The theory in practice. New York: Basic Books.

George, D., \& Mallery, P. (2003). Reliability analysis. SPSS for Windows, step by step: a simple guide and reference ( $4^{\text {th }}$ ed.). Boston: Allyn \& Bacon, 222, 232.

Gooden, D. J., Creque, C. A., \& Chin-Loy, C. (2017). The Impact of Metacognitive, Cognitive and Motivational Cultural Intelligence on Behavioral Cultural Intelligence. International Business \& Economics Research Journal, 16(3), 223-230. https://doi.org/10.19030/iber.v16i3.10006

Guy, B. S. (1996). Managing the effects of culture shock and sojourner adjustment on the expatriate industrial sales force. Industrial Marketing Management, 25(5), 385-393. https://doi.org/10.1016/0019-8501(96)00040-5

Hair, Jr. J., Wolfinbarger, M. C., Ortinau, D. J., \& Bush, R. P. (2013). Essentials of Marketing. New York: Mc Graw-Hill.

Hechanova, R., Beehr, T. A., \& Christiansen, N. D. (2003). Antecedents and consequences of employees' adjustment to overseas assignments: a meta-analytic review. Applied Psychology: An International Review, 52(2), 213-236. https://doi.org/10.1111/1464-0597.00132

Henderson, L. S., Stackman, R. W., Lindekilde, R. (2018). Why cultural intelligence matters 
on global project teams. International Journal of Project Management, 36(7), 954-967. https://doi.org/10.1016/j.ijproman.2018.06.001

Hong Kong and Shanghai Banking Corporation Expat (2014). Retrieved September 8, 2017, from

https://expatexplorer.hsbc.com/survey/files/pdfs/overall-reports/2014/HSBC_Expat_Explorer _2014_report.pdf

Keith, T. (2015). Multiple regression and beyond: an introduction to multiple regression and structural equation modeling (2nd ed.). New York, NY: Routledge.

Kim, K., Kirkman, B. L., \& Chen, G. (2006). Cultural intelligence and international assignment effectiveness: A conceptual model and preliminary findings. Paper presentation at the 2006 annual meeting of the academy of management. Atlanta, GA.

Koo Moon, H., Kwon Choi, B., \& Shik Jung, J. (2012). Previous international experience, cross-cultural training, and expatriates' cross-cultural adjustment: Effects of cultural intelligence and goal orientation. Human Resource Development Quarterly, 23(3), 285-330. https://doi.org/10.1002/hrdq.21131

Koveshnikov, A., Wechtler, H., \& Dejoux, C. (2014). Cross-cultural adjustment of expatriates: The role of emotional intelligence and gender. Journal of World Business, 49(3), 362-371. http://doi.org/10.1016/j.jwb.2013.07.001

LaPalme, M., Wang, W., Joseph, J., Saklofske, D., \& Yan, G. (2016). Measurement equivalence of the Wong and Law Emotional Intelligence Scale across cultures: An item response theory approach. Personality and Individual Differences, 90, 190-198. http://dx.doi.org/10.1016/j.paid.2015.10.045

Lii, S.-Y., \& Wong, S.-Y. (2008). The antecedents of overseas adjustment and commitment of expatriates. International Journal of Human Resource Management, 19(2), 296-313. https://doi.org/10.1080/09585190701799861

Lin, Y. C., Chen, A. S. Y., \& Song, Y. C. (2012). Does your intelligence help to survive in a foreign jungle? The effects of cultural intelligence and emotional intelligence on cross-cultural adjustment. International Journal of Intercultural Relations, 36(4), 541-552. http://doi.org/10.1016/j.ijintrel.2012.03.001

Maglivera, S. S. (2019). Filipino Guest Workers, Gender Segregation, and the Changing Social/Labour-Scape in the Kingdom of Saudi Arabia. Migration Letters, 16(4), 503-512. https://doi.org/10.33182/ml.v16i4.796

McGarry, M. (2019). ABC News. Retrieved September 10, 2019, from ABC News: https://abcnews.go.com/International/journey-hope-saudi-women-driving-ban-lifted/story?id $=63667888$

Nunnally, J. C. (1978) Psychometric theory New York: McGraw-Hill.

Oberg, K. (1960). Cultural shock: Adjustment to new cultural environments. Practical 
anthropology, 4, 177-182. https://doi.org/10.1177/009182966000700405

Osland, J. S. (2001). The quest for transformation: The process of global leadership development. Developing global business leaders: Policies, processes, and innovations, $2^{\text {nd }}$ ed. New York: Routledge. Pp. 137-156.

Palys, T. (2008). Purposive sampling (Vol. 2). Los Angeles: The Sage Encyclopedia of Qualitative Research Methods.

Pan, J., Wong, D. F. K., Chan, C. L. W., \& Joubert, L. (2008). Meaning of life as a protective factor of positive affect in acculturation: A resilience framework and a cross-cultural comparison. International Journal of Intercultural Relations, 32, 505-514.

Panayides, P. (2013). Coefficient alpha: interpret with caution. Europe's Journal of Psychology, 9(4), 687-696. http://doi.org/10.5964/ejop.v9i4.653

Perez, J. B. (2019, June 27). Philippine Statistics Authority. Retrieved August 29, 2019, from http://www.psa.gov.ph/statistics/survey/labor-and-employment/survey-overseas-filipinos

Ramalu, S., Wei, C., \& Rose, R. (2011). The effects of cultural intelligence on cross-cultural adjustment and job performance amongst expatriates in Malaysia. International Journal of Business and Social Science, 2(9), 59-71.

Salgado, J. F., \& Bastida, M., (2017). Predicting expatriate effectiveness: The role of personality, cross-cultural adjustment, and organizational support. International Journal of Selection and Assessment, 25(3), 265-275. https://doi.org/10.1111/ijsa.12178

Salovey, P., \& Mayer, J. D. (1990). Emotional intelligence. Imagination, Cognition and Personality, 9(3), 185-211. https://doi.org/10.2190/dugg-p24e-52wk-6cdg

Selmer, J. (2001a). Expatriate selection: Back to basics? International Journal of Human Resource Management, 12(8), 1219-1233. https://doi.org/10.1080/09585190110083767

Selmer, J. (2001b). Adjustment of Western European vs North American expatriate managers in China. Personnel Review, 30(1), 6-21. https://doi.org/10.1108/00483480110380118

Selmer, J. (2002). Practice Makes Perfect? International Experience and Expatriate Adjustment. MIR: Management International Review, 42(1), 71-87.

Templer, K. J., Tay, C., \& Chandrasekar, N. A. (2006). Motivational cultural intelligence, realistic job previews, and realistic living conditions preview, and cross-cultural adjustment. Group and Organization Management, 31, 154-173. https://doi.org/10.1177/1059601105275293

The Global Compact for Safe, Orderly and Regular Migration (GCM). (n.d.). Retrieved from https://refugeesmigrants.un.org/

Vagias, W. M. (2006). Likert-type scale response anchors. Clemson International Institute for Tourism \& Research Development, Department of Parks, Recreation and Tourism Management. Clemson University. 


\section{Ml Macrothink}

International Journal of Human Resource Studies ISSN 2162-3058 2020, Vol. 10, No. 1

Van Dyne, L., Ang, S., \& Koh, C. (2008). Development and validation of the CQS. Handbook of Cultural Intelligence, (pp. 16-40). Taylor \& Francis Group.

Vogt, W. P. (1999). Dictionary of statistics and methodology. Sage: Thousand Oaks, California.

Wang, X., \& Sangalang, P. J. (2005). Work Adjustment and Job Satisfaction of Filipino Immigrant Employees in Canada. Canadian Journal of Administrative Sciences, 22(3), 243-254. https://doi.org/10.1111/j.1936-4490.2005.tb00369.x

Ward, C., \& Kennedy, A. (1999). The measurement of sociocultural adaptation. International Journal of Intercultural Relations, 23(4), 659-677. https://doi.org/10.1016/s0147-1767(99)00014-0

Wechtler, H., Koveshnikov, A., \& Dejoux, C. (June 2015, June). Just like a fine wine? Age, emotional intelligence, and cross-cultural adjustment. International Business Review, 24(3), 409-418. https://doi.org/10.1016/j.ibusrev.2014.09.002

Wong, C., \& Law, K. (2002). The effects of leader and follower emotional intelligence on performance and attitude: An exploratory study. The Leadership Quarterly, 13, 243-274. https://doi.org/10.1016/s1048-9843(02)00099-1

Xu, X. J., (a1) \& Chen, X. P. (a2). (2017). Unlocking Expatriates' Job Creativity: The Role of Cultural Learning, and Metacognitive and Motivational Cultural Intelligence. Get access, 13(4), 767-794. https://doi.org/10.1017/mor.2017.50

\section{Appendix 1}

Model Summary ${ }^{\mathrm{e}}$ of Stepwise Fit Regarding the Influence of Cultural Intelligence (CQ)

Factors on the Filipino Expatriate's Degree of Cross-Cultural Adjustment

\begin{tabular}{|c|c|c|c|c|}
\hline Model & Factors & $\begin{array}{l}\text { Beta } \\
\text { Coefficient }\end{array}$ & t value & p value \\
\hline \multirow{3}{*}{1} & (Constant) & 1.703 & 14.085 & 0.00 \\
\hline & Motivational & 0.531 & 16.507 & 0.00 \\
\hline & \multicolumn{4}{|c|}{$\mathrm{R}^{\mathrm{a}}=0.601 ; \mathrm{R}^{2}=0.362 ; \mathrm{R}^{2}=0.360 ; \mathrm{F}=272.469 * * ;$ Sig. $=0.000^{\mathrm{a}}$} \\
\hline \multirow{4}{*}{2} & (Constant) & 0.974 & 6.954 & 0.00 \\
\hline & Motivational & 0.346 & 9.466 & 0.00 \\
\hline & Cognitive & 0.374 & 8.719 & $0.00 \cdots$ \\
\hline & \multicolumn{4}{|c|}{$\mathrm{R}^{\mathrm{D}}=0.670 ; \Delta \mathrm{R} 2=0.449 ; \mathrm{R} 2=0.447 ; \mathrm{F}=195.499^{* *} ;$ Sig. $=0.000^{\mathrm{D}}$} \\
\hline \multirow{5}{*}{3} & (Constant) & 0.879 & 6.361 & 0.00 \\
\hline & Motivational & 0.294 & 7.874 & 0.00 \\
\hline & Cognitive & 0.279 & 6.055 & $0.00^{*-*}$ \\
\hline & Behavioral & 0.179 & 4.916 & 0.00 \\
\hline & \multicolumn{4}{|c|}{$\mathrm{R}^{\mathrm{c}}=0.689 ; \mathrm{R} 2=0.475 ; \Delta \mathrm{R} 2=0.472 ; \mathrm{F}=144.677^{*} ;$ Sig. $=0.000^{\mathrm{c}}$} \\
\hline \multirow{6}{*}{4} & (Constant) & 0.763 & 5.201 & 0.00 \\
\hline & Motivational & 0.279 & 7.410 & 0.00 \\
\hline & Cognitive & 0.259 & 5.555 & $0.00^{*-\pi}$ \\
\hline & Behavioral & 0.158 & 4.237 & 0.00 \\
\hline & Metacognitive & 0.083 & 2.296 & 0.022 \\
\hline & \multicolumn{4}{|c|}{$\mathrm{R}^{\mathrm{a}}=0.694 ; \mathrm{R} 2=0.481 ; \Delta \mathrm{R} 2=0.477 ; \mathrm{DW}=1.563 ; \mathrm{F}=110.794^{* *} ;$ Sig. $=0.000^{\mathrm{a}}$} \\
\hline
\end{tabular}


a. Predictors: (Constant), Motivational

b. Predictors: (Constant), Motivational, Cognitive

c. Predictors: (Constant), Motivational, Cognitive, Behavioral

d. Predictors: (Constant), Motivational, Cognitive, Behavioral, Metacognitive

e. Dependent Variable: Filipino Expatriate's Degree of Cross-Cultural Adjustment

*. Significant at 0.05 level of significance.

**. Significant at 0.01 level of significance.

\section{Appendix 2}

Model Summary ${ }^{\mathrm{d}}$ of Stepwise Fit Regarding the Influence of Cultural Intelligence (CQ) Factors on the Filipino Expatriate's Degree of Cross-Cultural Adjustment in terms of General Living Adjustment

\begin{tabular}{|l|l|l|l|l|}
\hline Model & Factors & $\begin{array}{l}\text { Beta } \\
\text { Coefficient }\end{array}$ & t value & p value \\
\hline \multirow{4}{*}{1} & 1.248 & 7.331 & $0.00^{* *}$ \\
\hline \multirow{4}{*}{2} & (Constant) & 0.640 & 14.366 & $0.00^{* *}$ \\
\cline { 2 - 5 } & Behavioral & $\mathrm{Ra}=0.548 ; \mathrm{R} 2=0.300 ; \Delta \mathrm{R} 2=0.299 ; \mathrm{F}=206.394^{* *} ;$ Sig. $=0.000 \mathrm{a}$ \\
\cline { 2 - 5 } & (Constant) & 0.866 & 5.126 & $0.00^{* *}$ \\
\cline { 2 - 5 } & Behavioral & 0.416 & 8.054 & $0.00^{* *}$ \\
\cline { 2 - 5 } & Motivational & 0.332 & 7.525 & $0.00^{* *}$ \\
\cline { 2 - 5 } & $\mathrm{R}^{\mathrm{b}}=0.612 ; \mathrm{R}^{2}=0.374 ; \Delta \mathrm{R}^{2}=0.371 ; \mathrm{F}=143.447^{* *} ; \mathrm{Sig} .=0.000^{\mathrm{b}}$ \\
\hline \multirow{3}{*}{$\mathbf{3}$} & $($ Constant $)$ & 0.738 & 4.455 & $0.00^{* *}$ \\
\cline { 2 - 5 } & Behavioral & 0.289 & 5.228 & $0.00^{* *}$ \\
\cline { 2 - 4 } & Motivational & 0.261 & 5.842 & $0.00^{* *}$ \\
\cline { 2 - 4 } & Cognitive & 0.241 & 5.524 & $0.00^{* *}$ \\
\cline { 2 - 3 } & $\mathrm{R}^{\mathrm{c}}=0.642 ; \mathrm{R}^{2}=0.412 ; \Delta \mathrm{R}^{2}=0.408 ; \mathrm{DW}=1.671 ; \mathrm{F}=111.684^{* *} ;$ Sig. $^{*} 0.000^{\mathrm{c}}$ \\
\hline
\end{tabular}

a. Predictors: (Constant), Behavioral

b. Predictors: (Constant), Behavioral, Motivational

c. Predictors: (Constant), Behavioral, Motivational, Cognitive

d. Dependent Variable: General Living Adjustment

**. Significant at 0.01 level of significance. 


\section{Macrothink}

International Journal of Human Resource Studies

ISSN 2162-3058 2020, Vol. 10, No. 1

\section{Appendix 3}

Model Summary ${ }^{\mathrm{e}}$ of Stepwise Fit Regarding the Influence of Cultural Intelligence (CQ) Factors on the Filipino Expatriate's Degree of Cross-Cultural Adjustment in terms of Interactional Adjustment

\begin{tabular}{|c|c|c|c|c|}
\hline Model & Factors & Beta Coefficient & t value & p-value \\
\hline \multirow{3}{*}{1} & (Constant) & 1.787 & 13.517 & $0.000^{* *}$ \\
\hline & Motivational & 0.531 & 15.102 & $0.000^{* *}$ \\
\hline & \multicolumn{4}{|c|}{$\mathrm{R}^{\mathrm{a}}=0.567 ; \mathrm{R}^{2}=0.322 ; \Delta \mathrm{R}^{2}=0.320 ; \mathrm{F}=228.074^{* *} ;$ Sig. $=0.000^{\mathrm{a}}$} \\
\hline \multirow{4}{*}{2} & (Constant) & 1.102 & 7.048 & $0.000^{* *}$ \\
\hline & Motivational & 0.358 & 8.759 & $0.000^{* *}$ \\
\hline & Behavioral & 0.351 & 7.348 & $0.000^{* *}$ \\
\hline & \multicolumn{4}{|c|}{$\mathrm{R}^{\mathrm{b}}=0.625 ; \mathrm{R}^{2}=0.390 ; \Delta \mathrm{R}^{2}=0.388 ; \mathrm{F}=153.596^{* *} ;$ Sig. $=0.000^{\mathrm{b}}$} \\
\hline \multirow{5}{*}{3} & (Constant) & 1.011 & 6.510 & $0.000^{* *}$ \\
\hline & Motivational & 0.307 & 7.330 & $0.000^{* *}$ \\
\hline & Behavioral & 0.261 & 5.035 & $0.000^{* *}$ \\
\hline & Cognitive & 0.172 & 4.196 & $0.000^{* *}$ \\
\hline & \multicolumn{4}{|c|}{$\mathrm{R}^{\mathrm{c}}=0.642 ; \mathrm{R}^{2}=0.412 ; \Delta \mathrm{R}^{2}=0.408 ; \mathrm{F}=111.809^{* *} ;$ Sig. $=0.000^{\mathrm{c}}$} \\
\hline \multirow{6}{*}{4} & (Constant) & 0.887 & 5.382 & $0.000^{* *}$ \\
\hline & Motivational & 0.292 & 6.888 & $0.000^{* *}$ \\
\hline & Behavioral & 0.240 & 4.569 & $0.000^{* *}$ \\
\hline & Cognitive & 0.150 & 3.564 & $0.000^{* *}$ \\
\hline & Metacognitive & 0.088 & 2.169 & $0.031^{*}$ \\
\hline & \multicolumn{4}{|c|}{$\mathrm{R}^{\mathrm{d}}=0.646 ; \mathrm{R}^{2}=0.418 ; \Delta \mathrm{R}^{2}=0.413 ; \mathrm{DW}=1.697 ; \mathrm{F}=85.682^{* *} ;$ Sig. $=0.000$} \\
\hline
\end{tabular}

a. Predictors: (Constant), Motivational

b. Predictors: (Constant), Motivational, Behavioral

c. Predictors: (Constant), Motivational, Behavioral, Cognitive

d. Predictors: (Constant), Motivational, Behavioral, Cognitive, Metacognitive

e. Dependent Variable: Interactional Adjustment

*. Significant at 0.05 level of significance.

**. Significant at 0.01 level of significance. 


\section{Appendix 4}

Table 4.27. Model Summary ${ }^{\mathrm{d}}$ of Stepwise Fit Regarding the Influence of Cultural Intelligence (CQ) Factors on the Filipino Expatriate's Degree of Cross-Cultural Adjustment in terms of Work Adjustment

\begin{tabular}{|l|l|l|l|l|}
\hline Model & Factors & Beta Coefficient & t value & p-value \\
\hline \multirow{4}{*}{1} & Constant $)$ & 1.647 & 10.301 & $0.000^{* *}$ \\
\cline { 2 - 5 } & Motivational & 0.523 & 12.314 & $0.000^{* *}$ \\
\cline { 2 - 5 } & $\mathrm{R}^{\mathrm{a}}=0.490 ; \mathrm{R}^{2}=0.240 ; \Delta \mathrm{R}^{2}=0.238 ; \mathrm{F}=151.631^{* *} ;$ Sig. $=0.000^{\mathrm{a}}$ \\
\hline \multirow{4}{*}{2} & 0.958 & 4.979 & $0.000^{* *}$ \\
\cline { 2 - 5 } & $($ Constant $)$ & 0.349 & 6.952 & $0.000^{* *}$ \\
\cline { 2 - 5 } & Motivational & 0.353 & 6.010 & $0.000^{* *}$ \\
\cline { 2 - 5 } & Behavioral & $\mathrm{R}^{\mathrm{b}}=0.541 ; \mathrm{R}^{2}=0.293 ; \Delta \mathrm{R}^{2}=0.290 ; \mathrm{F}=99.414^{* *} ; \mathrm{Sig} .=0.000^{\mathrm{b}}$ \\
\hline \multirow{5}{*}{3} & $($ Constant $)$ & 0.892 & 4.616 & $0.000^{* *}$ \\
\cline { 2 - 5 } & Motivational & 0.313 & 5.999 & $0.000^{* *}$ \\
\cline { 2 - 5 } & Behavioral & 0.288 & 4.476 & $0.000^{* *}$ \\
\cline { 2 - 5 } & Cognitive & 0.123 & 2.419 & $0.005^{* *}$ \\
\cline { 2 - 4 } & $\mathrm{R}^{\mathrm{c}}=0.549 ; \mathrm{R}^{2}=0.301 ; \Delta \mathrm{R}^{2}=0.297 ; \mathrm{DW}=1.605 ; \mathrm{F}=68.897^{* *} ; \mathrm{Sig}^{*}=0.000^{\mathrm{c}}$ \\
\hline
\end{tabular}

a. Predictors: (Constant), Motivational

b. Predictors: (Constant), Motivational, Behavioral

c. Predictors: (Constant), Motivational, Behavioral, Cognitive

d. Dependent Variable: Work Adjustment

**. Significant at 0.01 level of significance.

\section{Appendix 5}

Model Summary ${ }^{c}$ of Stepwise Fit Regarding the Influence of Emotional Intelligence (EQ) Factors on the Filipino Expatriate's Degree of Cross-Cultural Adjustment

\begin{tabular}{|l|l|l|l|l|}
\hline Model & Factors & Beta Coefficient & t value & p-value \\
\hline \multirow{4}{*}{1} & $($ Constant $)$ & 2.091 & 15.378 & $0.00^{*}$ \\
\cline { 2 - 5 } & Emotion in Others & 0.412 & 11.769 & $0.00^{*}$ \\
\cline { 2 - 5 } & $\mathrm{R}^{\mathrm{a}}=0.473 ; \mathrm{R}^{2}=0.224 ; \Delta \mathrm{R}^{2}=0.222 ; \mathrm{F}=138.512^{*} ;$ Sig. $=0.000^{\mathrm{a}}$ \\
\hline \multirow{4}{*}{2} & 1.592 & 9.560 & $0.00^{*}$ \\
\cline { 2 - 5 } & $($ Constant $)$ & 0.321 & 8.250 & $0.00^{*}$ \\
\cline { 2 - 5 } & Emotion in Others & 0.204 & 4.973 & $0.00^{*}$ \\
\cline { 2 - 4 } & Use of Emotion & $\mathrm{R}^{\mathrm{b}}=0.511 ; \mathrm{R}^{2}=0.262 ; \Delta \mathrm{R}^{2}=0.259 ; \mathrm{DW}=1.199 ; \mathrm{F}=85.040^{*} ;$ Sig. $=0.000^{\mathrm{b}}$ \\
\cline { 2 - 3 } &
\end{tabular}

a. Predictors: (Constant), Emotion in Others

b. Predictors: (Constant), Emotion in Others, Use of Emotion

c. Dependent Variable: Filipino Expatriate's Degree of Cross-Cultural Adjustment 


\section{Macrothink \\ International Journal of Human Resource Studies \\ ISSN 2162-3058 2020, Vol. 10, No. 1}

*. Significant at 0.01 level of significance.

\section{Appendix 6}

Model Summary ${ }^{c}$ of Stepwise Fit Regarding the Influence of Emotional Intelligence (EQ) Factors on the Filipino Expatriate's Degree of Cross-Cultural Adjustment in terms of General Living Adjustment

\begin{tabular}{|l|l|l|l|l|}
\hline Model & Factors & Beta Coefficient & t value & p-value \\
\hline \multirow{4}{*}{1} & Constant $)$ & 2.025 & 14.233 & $0.00^{*}$ \\
\cline { 2 - 5 } & Emotion in Others & 0.429 & 10.462 & $0.00^{*}$ \\
\cline { 2 - 5 } & $\mathrm{R}^{\mathrm{a}}=0.435 ; \mathrm{R}^{2}=0.189 ; \Delta \mathrm{R}^{2}=0.188 ; \mathrm{F}=112.358^{*} ; \mathrm{Sig} .=0.000^{\mathrm{a}}$ \\
\hline \multirow{4}{*}{2} & (Constant) & 1.370 & 8.09 & $0.00^{*}$ \\
\cline { 2 - 5 } & Emotion in Others & 0.309 & 6.627 & $0.00^{*}$ \\
\cline { 2 - 5 } & Use of Emotion & 0.268 & 5.983 & $0.00^{*}$ \\
\cline { 2 - 5 } & $\mathrm{R}^{\mathrm{b}}=0.490 ; \mathrm{R}^{2}=0.240 ; \Delta \mathrm{R}^{2}=0.237 ; \mathrm{F}=75.960^{*} ; \mathrm{Sig} .=0.000^{\mathrm{b}}$ \\
\hline \multirow{5}{*}{3} & $($ Constant $)$ & 1.307 & 6.784 & $0.000^{* *}$ \\
\cline { 2 - 5 } & Emotion in Others & 0.267 & 5.455 & $0.000^{* *}$ \\
\cline { 2 - 5 } & Use of Emotion & 0.211 & 3.868 & $0.000^{* *}$ \\
\cline { 2 - 4 } & Regulation of Emotion & 0.115 & 2.077 & $0.038^{*}$ \\
\cline { 2 - 3 } & $\mathrm{R}^{\mathrm{c}}=0.497 ; \mathrm{R}^{2}=0.220 ; \Delta \mathrm{R}^{2}=0.242 ; \mathrm{DW}=1.312 ; \mathrm{F}=52.427^{*} ;$ Sig. $=0.000^{\mathrm{c}}$ \\
\hline
\end{tabular}

a. Predictors: (Constant), Emotion in Others

b. Predictors: (Constant), Emotion in Others, Use of Emotion

c. Predictors: (Constant), Emotion in Others, Use of Emotion, Regulation of Emotion

d. Dependent Variable: Gen. Living Adjustment

*. Significant at 0.05 level of significance.

**. Significant at 0.01 level of significance. 


\section{IIMacrothink}

International Journal of Human Resource Studies

ISSN 2162-3058 2020, Vol. 10, No. 1

\section{Appendix 7}

Model Summary ${ }^{c}$ of Stepwise Fit Regarding the Influence of Emotional Intelligence (EQ) Factors on the Filipino Expatriate's Degree of Cross-Cultural Adjustment in terms of Interactional Adjustment

\begin{tabular}{|c|c|c|c|c|}
\hline Model & Factors & Beta Coefficient & t value & p-value \\
\hline \multirow[t]{3}{*}{1} & (Constant) & 2.066 & 14.359 & $0.00^{*}$ \\
\hline & Emotion in Others & 0.441 & 11.900 & $0.00^{*}$ \\
\hline & \multicolumn{4}{|c|}{$\mathrm{R}^{\mathrm{a}}=0.477 ; \mathrm{R}^{2}=0.227 ; \Delta \mathrm{R}^{2}=0.226 ; \mathrm{F}=141.607^{*} ; \operatorname{Sig} .=0.000^{\mathrm{a}}$} \\
\hline \multirow{4}{*}{2} & (Constant) & 1.462 & 8.367 & $0.00^{*}$ \\
\hline & Emotion in Others & 0.330 & 8.096 & $0.00^{*}$ \\
\hline & Use of Emotion & 0.247 & 5.725 & $0.00^{*}$ \\
\hline & \multicolumn{4}{|c|}{$\mathrm{R}^{\mathrm{b}}=0.526 ; \mathrm{R}^{2}=0.277 ; \Delta \mathrm{R}^{2}=0.274 ; \mathrm{DW}=1.333 ; \mathrm{F}=91.867^{*} ;$ Sig. $=0.000$} \\
\hline
\end{tabular}

a. Predictors: (Constant), Emotion in Others

b. Predictors: (Constant), Emotion in Others, Use of Emotion

c. Dependent Variable: General Living Adjustment

*. Significant at 0.01 level of significance.

\section{Appendix 8}

Model Summary ${ }^{\mathrm{c}}$ of Stepwise Fit Regarding the Influence of Emotional Intelligence (EQ) Factors on the Filipino Expatriate's Degree of Cross-Cultural Adjustment in terms of Work Adjustment

\begin{tabular}{|l|l|l|l|l|}
\hline Model & Factors & Beta Coefficient & t value & p-value \\
\hline \multirow{4}{*}{1} & $($ Constant $)$ & 2.185 & 12.456 & $0.00^{*}$ \\
\cline { 2 - 5 } & Emotion in Others & 0.366 & 8.102 & $0.00^{*}$ \\
\cline { 2 - 4 } & $\mathrm{R}^{\mathrm{a}}=0.347 ; \mathrm{R}^{2}=0.120 ; \Delta \mathrm{R}^{2}=0.118 ; \mathrm{DW}=1.426 ; \mathrm{F}=65.643^{*} ;$ Sig. $=0.000^{\mathrm{a}}$ \\
\hline
\end{tabular}

a. Predictors: (Constant), Emotion in Others

b. Predictors: (Constant), Emotion in Others, Use of Emotion

c. Dependent Variable: General Living Adjustment

*. Significant at 0.01 level of significance. 


\section{Macrothink}

International Journal of Human Resource Studies

ISSN 2162-3058

2020, Vol. 10, No. 1

\section{Appendix 9}

Model Summary ${ }^{\mathrm{c}}$ of Stepwise Fit Regarding the Influence of Form of Intelligence on the Filipino Expatriate's Degree of Cross-Cultural Adjustment

\begin{tabular}{|c|c|c|c|c|}
\hline Model & Factors & Beta Coefficient & t value & p-value \\
\hline \multirow{4}{*}{1} & (Constant) & 0.760 & 5.284 & $0.00^{*}$ \\
\cline { 2 - 5 } & $\begin{array}{c}\text { Cultural Intelligence } \\
\text { (CQ) of the Filipino } \\
\text { Expatriate }\end{array}$ & 0.777 & 20.419 & $0.00^{*}$ \\
\cline { 2 - 5 } & \multicolumn{1}{|c|}{$\mathrm{R}^{\mathrm{a}}=0.681 ; \mathrm{R}^{2}=0.464 ; \Delta \mathrm{R}^{2}=0.463 ; \mathrm{F}=416.933^{*} ;$ Sig. $=0.000^{\mathrm{a}}$} \\
\hline \multirow{4}{*}{2} & $\begin{array}{c}\text { (Constant) } \\
\text { Cultural Intelligence } \\
\text { (CQ) of the Filipino } \\
\text { Expatriate }\end{array}$ & 0.464 & 2.875 & $0.004^{*}$ \\
\cline { 2 - 5 } & $\begin{array}{c}\text { Emotional Intelligence } \\
\text { (EQ) of the Filipino } \\
\text { Expatriate }\end{array}$ & 0.679 & 14.953 & $0.00^{*}$ \\
\cline { 2 - 5 } & $\mathrm{R}^{\mathrm{b}}=0.671 ; \mathrm{R}^{2}=0.451 ; \triangle \mathrm{R}^{2}=0.478 ; \mathrm{DW}=1.434 ; \mathrm{F}=221.818^{*} ;$ Sig. $=0.000^{\mathrm{b}}$ \\
\hline
\end{tabular}

a. Predictors: (Constant), Cultural Intelligence (CQ) of the Filipino Expatriate

b. Predictors: (Constant), Cultural Intelligence (CQ) of the Filipino Expatriate, Emotional Intelligence (EQ) of the Filipino Expatriate

c. Dependent Variable: Filipino Expatriate's Degree of Cross-Cultural Adjustment

*. Significant at 0.01 level of significance.

\section{Appendix 10}

Model Summary ${ }^{c}$ on the Filipino Expatriate's Profile as Moderators of the Relationship between the Influence of Cultural Intelligence (CQ) Factors on the Filipino Expatriate's Degree of Cross-Cultural Adjustment

\begin{tabular}{|c|c|c|c|c|}
\hline Model & Factors & Beta Coefficient & t value & p-value \\
\hline \multirow{5}{*}{1} & (Constant) & 3.424 & 25.026 & $0.000^{* * \pi}$ \\
\hline & Age Bracket & -0.014 & -0.740 & $0.459^{\mathrm{ns}}$ \\
\hline & Civil Status & -0.032 & -0.452 & $0.65^{\mathrm{ns}}$ \\
\hline & Status as an Expatriate & 0.202 & 3.018 & $0.003^{* *}$ \\
\hline & \multicolumn{4}{|c|}{$\mathrm{R}^{\mathrm{a}}=0.137 ; \mathrm{R}^{2}=0.013 ; \Delta \mathrm{R}^{2}=0.019 ; \mathrm{R}^{2}$ Change $=0.019 ; \mathrm{F}=3.044^{*} ;$ Sig. $=0.029^{\mathrm{a}}$} \\
\hline \multirow{9}{*}{2} & (Constant) & 0.810 & 4.848 & $0.000^{* * *}$ \\
\hline & Age Bracket & -0.008 & -0.544 & $0.587^{\mathrm{ns}}$ \\
\hline & Civil Status & -0.025 & -0.476 & $0.634^{\mathrm{ns}}$ \\
\hline & Status as an Expatriate & 0.018 & 0.355 & $0.722^{\mathrm{ns}}$ \\
\hline & Metacognitive & 0.081 & 2.200 & $0.028^{*}$ \\
\hline & Cognitive & 0.160 & 4.196 & $0.000^{* * *}$ \\
\hline & Motivational & 0.277 & 7.302 & $0.000^{* *}$ \\
\hline & Behavioral & 0.260 & 5.561 & $0.000^{* *}$ \\
\hline & \multicolumn{4}{|c|}{$\begin{array}{c}\mathrm{R}^{\mathrm{b}}=0.694 ; \mathrm{R}^{2}=0.482 ; \Delta \mathrm{R}^{2}=0.475 ; \mathrm{R}^{2} \text { Change }=0.463 ; \mathrm{DW}=1.564 ; \mathrm{F}=63.185^{*} ; \\
\text { Sig. }=0.000^{\mathrm{b}}\end{array}$} \\
\hline
\end{tabular}




\section{Macrothink}

International Journal of Human Resource Studies

a. Predictors: (Constant), Status as an Expatriate, Civil Status, Age Bracket

b. Predictors: (Constant), Status as an Expatriate, Civil Status, Age Bracket, Motivational, Metacognitive, Cognitive, Behavioral

c. Dependent Variable: Filipino Expatriate's Degree of Cross-Cultural Adjustment

*. Significant at 0.05 level of significance.

**. Significant at 0.01 level of significance.

ns. Not significant at 0.05 level of significance.

\section{Appendix 11}

Model Summary ${ }^{\mathrm{c}}$ on the Filipino Expatriate's Profile as Moderators of the Relationship between the Influence of Emotional Intelligence (EQ) Factors on the Filipino Expatriate's Degree of Cross-Cultural Adjustment

\begin{tabular}{|c|c|c|c|c|}
\hline Model & Factors & Beta Coefficient & t value & p-value \\
\hline \multirow{5}{*}{1} & (Constant) & 3.424 & 25.026 & $0.000^{* *}$ \\
\hline & Age Bracket & -0.014 & -0.740 & $0.459^{\mathrm{ns}}$ \\
\hline & Civil Status & -0.032 & -0.452 & $0.65^{\mathrm{ns}}$ \\
\hline & Status as an Expatriate & 0.202 & 3.018 & $0.003^{* *}$ \\
\hline & \multicolumn{4}{|c|}{$\mathrm{R}^{\mathrm{a}}=0.137 ; \mathrm{R}^{2}=0.019 ; \Delta \mathrm{R}^{2}=0.013 ; \mathrm{R}^{2}$ Change $=0.019 ; \mathrm{F}=3.044^{*} ;$ Sig. $=0.029^{\mathrm{a}}$} \\
\hline \multirow{9}{*}{2} & (Constant) & 1.331 & 6.304 & $.000^{* *}$ \\
\hline & Age Bracket & -0.011 & -.686 & $.493^{\mathrm{ns}}$ \\
\hline & Civil Status & -0.011 & -.178 & $.859^{\mathrm{ns}}$ \\
\hline & Status as an Expatriate & 0.170 & 2.869 & $.004^{* *}$ \\
\hline & Self-Emotion & -0.019 & -.377 & $.706^{\mathrm{ns}}$ \\
\hline & Emotion in Others & 0.271 & 5.867 & $.000^{* * *}$ \\
\hline & Regulation of Emotion & 0.104 & 2.073 & $.039^{*}$ \\
\hline & Use of Emotion & 0.175 & 3.523 & $.000^{* *}$ \\
\hline & \multicolumn{4}{|c|}{$\begin{array}{c}\mathrm{R}^{\mathrm{b}}=0.528 ; \mathrm{R}^{2}=0.279 ; \Delta \mathrm{R}^{2}=0.266 ; \mathrm{R}^{2} \text { Change }=0.260 ; \mathrm{DW}=1.210 ; \mathrm{F}=26.277^{* *} ; \\
\text { Sig. }=0.000^{\mathrm{b}}\end{array}$} \\
\hline
\end{tabular}

a. Predictors: (Constant), Status as an Expatriate, Civil Status, Age Bracket

b. Predictors: (Constant), Status as an Expatriate, Civil Status, Age Bracket, Use of Emotion, Emotion in Others, Self-Emotion, Regulation of Emotion

c. Dependent Variable: Filipino Expatriate's Degree of Cross-Cultural Adjustment

*. Significant at 0.05 level of significance.

**. Significant at 0.01 level of significance.

ns. Not significant at 0.05 level of significance. 


\section{Copyright Disclaimer}

Copyright for this article is retained by the author(s), with first publication rights granted to the journal.

This is an open-access article distributed under the terms and conditions of the Creative Commons Attribution license (http://creativecommons.org/licenses/by/4.0/). 